\title{
Video Resources Are Used to Assist Primary School Students to Evaluate the Effectiveness of Good Contact and Bad Contact Knowledge in Their Learning
}

\author{
Nahe Siugh ${ }^{1}$, Wjnimy Jehn ${ }^{2}$ \\ ${ }^{1}$ M.Sc. Nursing $2^{\text {nd }}$ yr. Student \\ ${ }^{2}$ Assistant Professor Era College of Nursing
}

\begin{abstract}
Background: The issue of child abuse has been recognized as a major global social problem prevalent within and outside the homes and among all socio-economic groups all over the world. Parents tend to apply harsh form of disciplinary actions without knowing it actually is an abuse. Due to the absence of knowledge, the parents, especially mothers show reluctance to report cases to authorities concerned with health care or legal protection. Objectives: The study was conducted with the objectives to assess the pre test and post test level of knowledge scores among mothers, to determine the effectiveness of video assisted teaching and to associate the pre test knowledge scores and their selected demographic variables. Methods: The researcher used a pre experimental research design. The research approach was evaluative approach. The study conducted in Lucknow City College at Lucknow. 60 samples were selected by using Non-probability purposive sampling technique. The data was collected by using structured questionnaires before after administration of video assisted teaching. Results: The finding of this study shows that, there was a significant improvement of knowledge among mothers of primary school children after administration of VAT. The mean and SD of post test knowledge score was $(19.97 \pm 1.79)$ and pre test knowledge score was (13.57 \pm 3.32$)$. The paired ' $t$ ' value (21.142) was found to be significant at $(<0.05)$ shows that there is a statistical difference between pre test and post test level of knowledge score. There was no significant association between the pretest knowledge scores and selected demographic variables at $(P<0.05)$.The result supported that, the knowledge of primary school children was improved after administration of VAT regarding Good Touch and Bad Touch. Conclusion: The study showed that the VAT was significantly effective in improving the knowledge scores of mothers of school going children regarding good touch and bad touch.
\end{abstract}

Keywords: Good Touch and Bad Touch, Video assisted teaching, Mothers, Primary school children

\section{Introduction}

Touch is a basic need of human existence. From the minute we are born to our last breath, touch nurtures us. [1] Touch, is a uniquely variable positive experience that is a channel through which parents (especially mothers) and children show love and affectionthat makes their bond stronger and child feel safe.Good touch heals and reinforces. Bad touch scars and degrades, and can lead to depression, helplessness, and suicide. Bad touch can have life-altering negative consequences.Error! Bookmark not defined.Good touch and bad touch is gradually learnt through a child's day to day activities. We can increase this learnt behavior by making an efforts to teach a child about the difference between good touch and bad touch in early age. The world wide survey was conducted and it is estimated that at least 1 in 10 girls and 1 in 20 boys had experienced sexual abuse in childhood. The children who experienced the sexual abuse are more prone to depression, eating disorder, drug and alcohol abuse, suicidal behavior, difficulty in concentration and more prone to become victim in adulthood. [2]

Child abuse, a global issue affects children of all ages, gender, races, ethnicities, in varied socioeconomic classes and is in the forefront in the line of widespread social issues and social problems. Child abuse occurs in many different forms such as physical, sexual, emotional and neglect; whereby irrespective of any form of abuse it has a traumatizing lifetime experience for the victim. [3]
The World Health Organization (WHO) 2016 defines child abuse and child maltreatment as "all forms of physical and/or emotional ill-treatment, sexual abuse, neglect or negligent treatment or commercial or other exploitation, resulting in actual or potential harm to the child's health, survival, development or dignity in the context of a relationship of responsibility, trust or power." [4] There are many factors in the etiology of child neglect and abuse. Parents' have low educational level, mother's young age, parents' absence, parents with neglect, abuse stories, parents with psychiatric disturbances, low socio-economic level, substance dependence of parents, unwanted pregnancy and having a step mother or father are among these factors. [5] Prevention of child abuse is an inevitable part of the society. The impact of child maltreatment can be profound. Child abuse and maltreatment affect various systems of the child which may later leads to many other disorders. When parents give more attention and are caring towards the children and discuss child's problem parents and specially mother can notice child's behavior and understand child better. [6]

\section{Material and Method}

A quantitative experimental, pre experimental, one group pre-test and post-test design was followed. The study was conducted between 15-07-19 to 22-07-19in Lucknow City College, Lucknow. The Institutional Ethical Committee approval was obtained before the study. Population of the 
study was mothers of primary school children those are studying in Lucknow City College, and who are willing to participate in the study. Non-Probability Purposive sampling was carried out on 60 samples. Informed consent of the participants was obtained.

Demographic variable such as Age, Marital Status, Religion, Place of Residence, Educational status of mothers, Employment status of mothers, Monthly family Income, Type of family, No. of children, Previous Knowledge. The Structured Knowledge questionnaire regarding Good touch and Bad touch.This section consists of 25 items containing questions related to Good touch and bad touch. Each item has one correct response among 4 options and it is awarded a score of 1 for the correct response according to the pre determined key.

\begin{tabular}{|c|c|}
\hline Aspects & Numbers of Questions \\
\hline Touch & 3 \\
\hline Abuse and its causes & 5 \\
\hline Disclosing problems & 3 \\
\hline Warning signs & 4 \\
\hline Preventive measures & 10 \\
\hline
\end{tabular}

Nominal data were described and expressed in frequency and percentage. Both descriptive and inferential statistics was used to analyze data. Inferential Statistics ' $t$ ' test, was used to find relationship of knowledge level with selected demographic variable. Descriptive statistics (frequency distribution and percentage, mean and SD) was used to analyze the socio-demographic.

\section{Strength and limitations}

The specified population assessed in this research study and standardized tools used were the strength of the study. Study is limited to the mothers of primary school children who are studying in Lucknow City College at Lucknow, and the effectiveness of video assisted teaching on knowledge of good touch and bad touch among mothers of primary school children.

\section{Results}

\section{Description of subjects}

During the study period, 60 mothers were enrolled in the study based inclusion criteria. The table 1: Table summarized that among 60 mothers, marital status majority of 47 mothers $(78.33 \%)$ were married. According to their religion, majority of 45 mothers $(75 \%)$ were Hindu,Place of residence of 39 mothers $(65 \%)$ were living in Urban,Educational status of 20 mothers (33.33\%) were senior secondary educated. Employmentstatus of 26 mothers $(43.33 \%)$ were unemployed.Monthly family income of 30 mothers $(50 \%)$ were belonging to Rs.20, 000-30,000. Type of family of 30 mothers $(50 \%)$ were living in nuclear family. Number of children of 32 mothers $(53.33 \%)$ were having two children.Majority of 41 mothers (68.33\%) have inadequate previous knowledge regarding Good touch and Bad touch.

\begin{tabular}{|c|c|c|c|}
\hline S No. & Demographic Data & \begin{tabular}{|c|} 
Frequency \\
$(\mathrm{F})$ \\
\end{tabular} & \begin{tabular}{|c|} 
Percentage \\
$(\%)$ \\
\end{tabular} \\
\hline \multirow[t]{5}{*}{1} & Marital Status & & \\
\hline & Single Parent & 4 & 6.67 \\
\hline & Married & 47 & 78.33 \\
\hline & Divorce & 8 & 13.33 \\
\hline & Widow & 1 & 1.67 \\
\hline \multirow[t]{3}{*}{2} & Religion & & \\
\hline & Hindu & 45 & 75 \\
\hline & Muslim & 15 & 25 \\
\hline \multirow[t]{3}{*}{3} & Place of Residence & & \\
\hline & Semi Urban & 21 & 35 \\
\hline & Urban & 39 & 65 \\
\hline \multirow[t]{6}{*}{4} & Educational status of mothers & & \\
\hline & Primary Education & 7 & 11.67 \\
\hline & Higher secondary education & 18 & 30 \\
\hline & Senior secondary education & 20 & 33.33 \\
\hline & Graduate & 12 & 20 \\
\hline & Post graduate & 3 & 5 \\
\hline \multirow[t]{6}{*}{5} & Employment status of mothers & & \\
\hline & Un employed & 26 & 43.33 \\
\hline & Un skilled worker & 8 & 13.33 \\
\hline & Semi skilled worker & 12 & 20 \\
\hline & Skilled worker & 10 & 16.67 \\
\hline & Professional & 4 & 6.67 \\
\hline \multirow[t]{5}{*}{6} & Monthly family Income & & \\
\hline & Below Rs. 20,000 & 10 & 16.67 \\
\hline & $20,001-30,000$ & 30 & $\mathbf{5 0}$ \\
\hline & $30,001-40,000$ & 13 & 21.66 \\
\hline & More than 40,000 & 7 & 11.67 \\
\hline \multirow[t]{4}{*}{7} & Type of family & & \\
\hline & Nuclear family & 30 & $\mathbf{5 0}$ \\
\hline & Joint family & 26 & 43.33 \\
\hline & Extended family & 4 & 6.67 \\
\hline \multirow[t]{4}{*}{8} & No. of children & & \\
\hline & One & 14 & 23.33 \\
\hline & Two & 32 & 53.33 \\
\hline & Three or more & 14 & 23.33 \\
\hline \multirow[t]{3}{*}{9} & Previous Knowledge & & \\
\hline & Yes & 19 & 31.67 \\
\hline & No & 41 & 68.33 \\
\hline
\end{tabular}

Table 2: Table showing mean and SD of age of mothers

\begin{tabular}{|c|c|c|c|}
\hline Category & Mean & SD & Mean (\%) \\
\hline Age & 29.47 & 4.27 & $49.11 \%$ \\
\hline
\end{tabular}

The table 2: the table reveals that mean age of the mothers is 29.47 and SD 4.27.

Table 3.1: Table showing pre test knowledge scores of the mothers

\begin{tabular}{|c|c|c|c|c|}
\hline \multirow{2}{*}{ Domains } & \multicolumn{4}{|c|}{ Pre Test } \\
\cline { 2 - 5 } & Max Score & Mean & SD & Mean $\%$ \\
\hline Touch & $\mathbf{3}$ & 2.07 & 0.87 & $\mathbf{6 9}$ \\
\hline Abuse and its Causes & $\mathbf{5}$ & 2.72 & 1.22 & $\mathbf{5 4 . 4}$ \\
\hline Disclosing Problems & $\mathbf{3}$ & 2.22 & 0.78 & $\mathbf{7 4}$ \\
\hline Warning Signs & $\mathbf{4}$ & 1.55 & 0.91 & $\mathbf{3 8 . 7 5}$ \\
\hline Preventive Measures & $\mathbf{1 0}$ & 4.98 & 1.69 & $\mathbf{4 9 . 8}$ \\
\hline Overall & $\mathbf{2 5}$ & $\mathbf{1 3 . 5 7}$ & $\mathbf{3 . 3 2}$ & $\mathbf{5 4 . 2 8}$ \\
\hline
\end{tabular}

Table 3 reveals that Domain wise mean knowledge of mothers regarding good touch and bad touch. $69 \%$ mean knowledge was found in Touch domain followed by $54.4 \%$ in abuse and its causes, $74 \%$ in Disclosing problems, $38.75 \%$ in Warning signs, and $49.8 \%$ in preventing measures. 
Overall pretest mean score on knowledge regarding good touch and bad touch among mothers of primary school children was 13.57 shows inadequate knowledge.

Table 3.2: Table showing pre test knowledge scores of the mothers

\begin{tabular}{|c|c|c|c|c|}
\hline \multirow{2}{*}{ Domains } & \multicolumn{4}{|c|}{ Post Test } \\
\cline { 2 - 5 } & Max Score & Mean & SD & Mean \% \\
\hline Touch & 3 & 2.98 & 0.13 & 99.33 \\
\hline Abuse and its Causes & 5 & 4.13 & 0.85 & 82.6 \\
\hline Disclosing Problems & 3 & 2.75 & 0.51 & 91.66 \\
\hline Warning Signs & 4 & 3.07 & 0.80 & 76.65 \\
\hline Preventive Measures & 10 & 7.02 & 1.42 & 70.2 \\
\hline Overall & 25 & 19.95 & 1.79 & 79.8 \\
\hline
\end{tabular}

Table: 3.2the table reveals that Aspect wise mean knowledge of mothers regarding good touch and bad touch. $99.33 \%$ mean knowledge was found in Touch aspect followed by $82.6 \%$ in abuse and its causes, $91.66 \%$ in Disclosing problems, $76.65 \%$ in Warning signs, and $70.2 \%$ in preventing measures.

Overall post test mean score on knowledge regarding good touch and bad touch among mothers of primary school children was 19.95 shows adequate knowledge.

Table 3.3: Comparison of pre \& post test scores to assess the level of knowledge regarding good touch and bad touch

\begin{tabular}{|c|c|c|c|c|c|}
\hline $\begin{array}{c}\text { Knowledge } \\
\text { Level }\end{array}$ & Scores & \multicolumn{2}{|c|}{ Pre Test } & \multicolumn{2}{c|}{ Post Test } \\
\cline { 3 - 6 } & Frequency & $\begin{array}{c}\text { Percentage } \\
\%\end{array}$ & Frequency & $\begin{array}{c}\text { Percentage } \\
\%\end{array}$ \\
\hline $\begin{array}{c}\text { Inadequate } \\
\text { knowledge }\end{array}$ & $0-13$ & 32 & 53.33 & 0 & 0 \\
\hline $\begin{array}{c}\text { Moderate } \\
\text { knowledge }\end{array}$ & $14-19$ & 25 & 41.67 & 19 & 31.67 \\
\hline $\begin{array}{c}\text { Adequate } \\
\text { knowledge }\end{array}$ & $20-25$ & 3 & 5 & 41 & 68.33 \\
\hline TOTAL & & 60 & 100 & 60 & 100 \\
\hline
\end{tabular}

Table: 3.3the table indicates the overall knowledge level of mothers regarding good touch and bad touch, in pre test there were 32 number $(53.33 \%)$ of the mothers with inadequate knowledge, 25 number $(41.67 \%)$ of the mothers with the moderate level of knowledge, 3 numbers $(5 \%)$ where in adequate knowledge where as in post test 19 number $(31.67 \%)$ of mothers were moderate knowledge,41 numbers $(68.33 \%)$ had adequate knowledge regarding good touch and bad touch.
Table 4: Paired " $t$ "-test values to assess the effectiveness of video assisted teaching on knowledge regarding good touch and bad touch among mothers of primary school children

\begin{tabular}{|c|c|c|c|c|c|c|}
\hline \multirow{2}{*}{ Domains } & \multicolumn{2}{|c|}{ Pre Test } & \multicolumn{2}{c|}{ Post Test } & \multirow{2}{*}{ 't' value } & \multirow{2}{*}{ P Value } \\
\cline { 2 - 6 } & Mean & SD & Mean & SD & & \\
\hline Touch & 2.07 & 0.87 & 2.98 & 0.13 & $\mathbf{7 . 9 9 1}$ & $\mathbf{0 . 9 4 0}$ \\
\hline Abuse And Its Causes & 2.72 & 1.22 & 4.13 & 0.85 & $\mathbf{7 . 3 7 6}$ & $\mathbf{0 . 9 7 4}$ \\
\hline Disclosing Problems & 2.22 & 0.78 & 2.75 & 0.51 & $\mathbf{4 . 8 4 3}$ & $\mathbf{0 . 3 2 4}$ \\
\hline Warning Signs & 1.55 & 0.91 & 3.07 & 0.79 & $\mathbf{1 2 . 8 9 3}$ & $\mathbf{0 . 0 6}$ \\
\hline Preventive Measures & 4.98 & 1.69 & 7.02 & 1.42 & $\mathbf{1 0 . 3 7 6}$ & $\mathbf{0 . 0 0 0}$ \\
\hline
\end{tabular}

The above Table 4 revealed that the mean difference of domain wise regarding good touch and bad touch. 0.91 mean difference was found in Touch Domain followed by ' $t$ ' value 7.991,1.41 in Abuse and its causes with their 7.376, 0.53 in Disclosing problems with their 4.843, 1.52 in Warning signs with their 12.893, and 2.04 in preventing measures there with $\mathbf{1 0 . 3 7 6}$.

The paired ' $t$ ' value shows that there is significant difference between pre test and post test level of knowledge at 0.05 level of significance. It indicates the effectiveness of video assisted teaching in improving the knowledge regarding good touch and bad touch among mothers of primary school children.

Table 4.1: Overall Mean percentage Knowledge Scores of Pre-test and Post-tests knowledge scores of pre-test

\begin{tabular}{|l|c|c|c|c|c|c|}
\hline Domains & Range Score & $\begin{array}{l}\text { Mean } \\
\text { Score }\end{array}$ & $\begin{array}{c}\text { Knowledge } \\
\text { Mean \% }\end{array}$ & $\begin{array}{c}\text { Score } \\
\text { SD }\end{array}$ & $\begin{array}{l}\text { Paired } \\
\text { 't' Test }\end{array}$ & P value \\
\hline Pre Test & $8-21$ & 13.57 & 54.28 & 3.32 & & \\
\hline Post Test & $15-24$ & 19.97 & 79.88 & 1.79 & 21.142 & 0.735 \\
\hline
\end{tabular}

Table 4.1indicates the overall mean percentage knowledge of pre-test and post-test on good touch and bad touch.The post-test mean percentage knowledge score was found higher (mean percentage $79.88 \%$ and SD 1.79 when compared with pre-test mean percentage knowledge score value which was $54.28 \%$ percentage with SD of 3.32 (mean knowledge enhancement score was $6.4,25.6 \%$ and SD 2.35 The statistical paired ' $t$ ' test implies that the difference in the pre-test and posttest value was found statistically significant at $5 \%$ level $(\mathrm{p}<0.05)$ with a paired ' $\mathrm{t}$ ' test value of 21.142 . There exists a statistical significance in the enhancement of level of knowledge score indicating the positive impact of video assisted teaching. Hence the stated research hypothesis $H_{1}$ is accepted.

Table 5: Chi-square test showing association between pre-test levels of knowledge with their selected demographic variables

\begin{tabular}{|c|c|c|c|c|c|c|c|c|c|}
\hline \multirow{2}{*}{ Demographic Variables } & \multicolumn{2}{|c|}{ Inadequate } & \multicolumn{2}{|c|}{ Moderate } & \multicolumn{2}{|c|}{ Adequate } & \multirow{2}{*}{ Chi Square Value } & \multirow{2}{*}{ Df } & \multirow{2}{*}{$P$ value } \\
\hline & $\mathrm{F}$ & $\%$ & $\mathrm{~F}$ & $\%$ & $\mathrm{~F}$ & $\%$ & & & \\
\hline \multicolumn{10}{|c|}{ Marital Status } \\
\hline Single Parent & 4 & 6.67 & $\mathbf{0}$ & 0 & $\mathbf{0}$ & 0 & 7.448 & 6 & 0.281 \\
\hline Married & 21 & 35 & 23 & 38.33 & 3 & 5 & & & \\
\hline Divorce & 6 & 10 & 2 & 3.33 & $\mathbf{0}$ & 0 & & & \\
\hline Widow & 1 & 1.67 & $\mathbf{0}$ & 0 & $\mathbf{0}$ & 0 & & & \\
\hline \multicolumn{10}{|c|}{ Religion } \\
\hline Hindu & 24 & 40 & 20 & 33.33 & 1 & 1.67 & 3.111 & 2 & 0.211 \\
\hline Muslim & 8 & 13.33 & 5 & 8.33 & 2 & 3.33 & & & \\
\hline \multicolumn{10}{|c|}{ Place of Residence } \\
\hline Semi Urban & 13 & 21.67 & 6 & 10 & 2 & 3.33 & & & \\
\hline Urban & 19 & 31.67 & 19 & 31.67 & 1 & 1.67 & 3.097 & 2 & 0.213 \\
\hline \multicolumn{10}{|c|}{ Educational status } \\
\hline Primary Education & 2 & 3.33 & 5 & 8.33 & $\mathbf{0}$ & 0 & 5.64 & 8 & 0.688 \\
\hline
\end{tabular}




\begin{tabular}{|c|c|c|c|c|c|c|c|c|c|}
\hline Higher secondary education & 10 & 16.67 & 8 & 13.33 & $\mathbf{0}$ & 0 & & & \\
\hline Senior secondary education & 11 & 18.33 & 7 & 11.67 & 2 & 3.33 & & & \\
\hline Graduate & 7 & 11.67 & 4 & 6.67 & 1 & 1.67 & & & \\
\hline Post graduate & 2 & 3.33 & 1 & 1.6 & $\mathbf{0}$ & 0 & & & \\
\hline \multicolumn{10}{|c|}{ Employment status } \\
\hline Un employed & 10 & 16.67 & 14 & 23.33 & 2 & 3.33 & 6.35 & 8 & 0.608 \\
\hline Un skilled worker & 6 & 10 & 2 & 3.33 & 0 & 0 & & & \\
\hline Semi skilled worker & 8 & 13.33 & 3 & 5 & 1 & 1.67 & & & \\
\hline Skilled worker & 6 & 10 & 4 & 6.67 & 0 & 0 & & & \\
\hline Professional & 2 & 3.33 & 2 & 3.33 & 0 & 0 & & & \\
\hline \multicolumn{10}{|c|}{ Monthly family Income } \\
\hline Below Rs. 20,000 & 2 & 3.33 & 7 & 11.67 & 1 & 1.67 & 11.257 & 6 & 0.081 \\
\hline $20,001-30,000$ & 21 & 35 & 9 & 15 & $\mathbf{0}$ & 0 & & & \\
\hline $30,001-40,000$ & 5 & 8.33 & 7 & 11.67 & 1 & 1.67 & & & \\
\hline More than 40,000 & 5 & 8.33 & 1 & 1.67 & 1 & 1.67 & & & \\
\hline \multicolumn{10}{|c|}{ Type of family } \\
\hline Nuclear family & 15 & 25 & 14 & 23.33 & 1 & 1.67 & 4.343 & 4 & 0.362 \\
\hline Joint family & 13 & 21.67 & 11 & 18.33 & 2 & 3.33 & & & \\
\hline Extended family & 4 & 6.67 & $\mathbf{0}$ & 0 & $\mathbf{0}$ & 0 & & & \\
\hline \multicolumn{10}{|c|}{ No. of children } \\
\hline One & 8 & 13.33 & 6 & 10 & $\mathbf{0}$ & 0 & 3.734 & 4 & 0.443 \\
\hline Two & 18 & 30 & 13 & 21.67 & 1 & 1.67 & & & \\
\hline Three or more & 6 & 10 & 6 & 10 & 2 & 3.33 & & & \\
\hline \multicolumn{10}{|c|}{ Previous Knowledge } \\
\hline Yes & 10 & 16.67 & 7 & 11.67 & 2 & 3.33 & & & \\
\hline No & 22 & 36.67 & 18 & 30 & 1 & 1.67 & 1.856 & 2 & 0.395 \\
\hline
\end{tabular}

The data presented in the table 5 shows that there was no significant statistical association found between the pre test level of knowledge scores with their selected sociodemographic variables among mothers of primary school children at 0.05 level of significance.

Table 5.1: Correlation between age and Mean knowledge score

\begin{tabular}{|c|c|c|}
\hline Variables & Mean & Correlation (r) \\
\hline Age & 29.47 & -0.107 \\
\hline Knowledge score & 13.57 & \\
\hline
\end{tabular}

Table 5.1 depicts relationship between age and knowledge score among mothers of primary school children. The coefficient correlation between age and knowledge score was calculated using Pearson's coefficient formula and it showed negative correlation $(r=-0.107)$ which was statistically significant at $\mathrm{p}<0.05$.

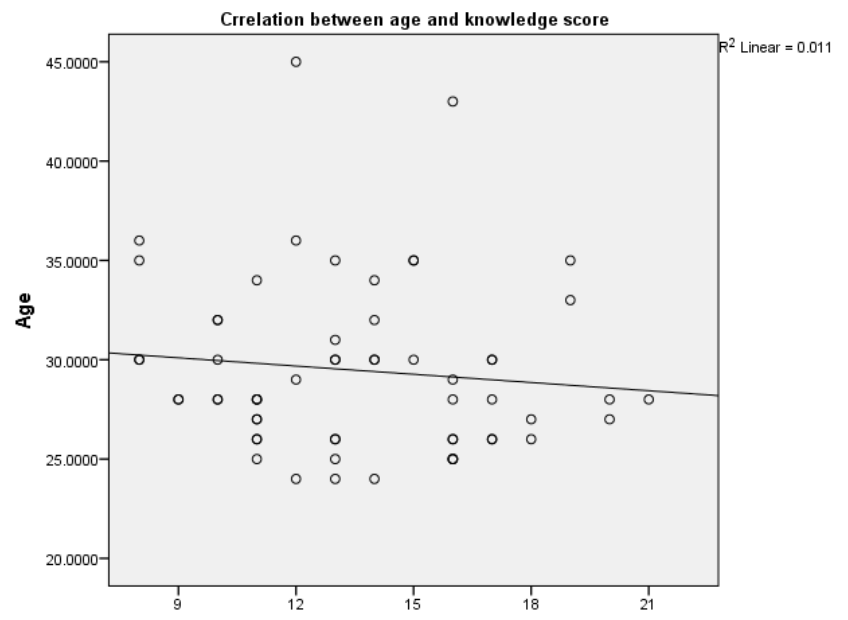

Therefore, it is concluded that level of knowledge and age among mothers of primary school children correlate to each other.

\section{Discussion}

In pre test the majority $32(53.33 \%)$ numbers of mothers with inadequate knowledge and $25(41.67 \%)$ number of mothers with moderate level of knowledge and only $3(5 \%)$ numbers of mother have adequate level of knowledge and overall mean score was $54 \%$.

This study findings were consistent with the study conducted by Debyani Das (2017) in which the knowledge score of mothers showed that $4 \%, 22 \%, 44 \%, 30 \%$ mothers had scored excellent, good, average, poor knowledge score respectively. Majority of mothers in the area of physical abuse (43\%), psychological abuse (38\%), sexual abuse $(29 \%)$ and neglect $(56 \%)$ had poor knowledge score. Majority of mothers in the area of definition and description (44\%), and prevention (46\%) scored average. There were significant association found between knowledge score with age $\left(\mathrm{x} 2=4.6^{*} ; \mathrm{p} 0.05\right)$ association between knowledge score with monthly family income. The study conclude that the most of mothers have average knowledge regarding child abuse and its prevention but mothers are usually overlook neglect as one of the categories of child-abuse and improvement in societal status of mothers in terms of education, occupation can be a step to prevent child abuse. [7]

In post test the majority $41(68.33 \%)$ number of mothers with adequate knowledge and 19 (31.67\%) number of teachers with moderate level of knowledge and overall mean score was $(79.8 \%)$. 
This study findings were consistent with the study conducted by Kaur A et,al; (2018) was clearly illustrate the maximum students have the poor knowledge regarding good touch and bad touch but after teaching program there is significant improvement in the knowledge regarding good touch and bad touch among school children. [8]

This study finding were consistent with the study conducted by Ms. Yaiphabee Abujamand Prof A. Santham in which 60 school children were selected by non-probability convenient sampling technique pre-test and post-test level of knowledge was assessed using CKAQ-Revision III 2. Children attendedthe structure teaching programme and 30 children did not attend the structured teaching programme. In the experiments group, $73.3 \%$ children were in the age of 10 years in the control group, $43.3 \%$ of children were in the age group of 11 years. The study examined that " $t$ " test was 12.034 at $\mathrm{d} p=0.05$ level, which shown a significant difference in the knowledge after structure teaching programme among school children. [9]

\section{Conclusion}

The study findings revealed that there was a significant improved the knowledge regarding good touch and bad touch after the video assisted teaching. The provision of video assisted teaching will motivate mothers and help them to improve the knowledge level. A similar study can be done with a large sample for generalization. A study can be carried out to evaluate the efficiency of other teaching strategies like structured teaching program, computer assisted teaching program etc. A similar study can be conducted to identify the various factors responsible for lack of knowledge of mothers regarding child abuse.

\section{Implications}

The Nursing personnel should be encouraged to participate in awareness programs regarding child abuse. They can organize continuing education programmes on the prevention of child abuse for nursing personnel and motivate them to educate the common public. Nurses should conduct health campaigns and should use different strategies to educate the mothers from preventing child abuse.

\section{Financial support and sponsorship}

Nil.

\section{Conflicts of interest}

There are no conflicts of interest.

\section{References}

[1] Daly, Joseph L.; Maza, Michael S.; and Daly, Colleen M. (2010) ""Gray Touch": Professional Issues in the Uncertain Zone Between "Good Touch" and "Bad Touch"," Marquette Elder's Advisor: Vol. 11: 2, Article 3. [cited 2018 Aug12] URL Available at: http://scholarship.law.marquette.edu/elders/vol11/iss2/3
[2] AmandeepKaur et.al,(2018) An Experimental Study to assess The Effectiveness Of Structured Teaching Program on Knowledge regarding Good Touch And Bad Touch Among Students, International Journal of Social Science and Humanities Research, Vol. 6,Issue2,pp:(735-

739).URLavailable:http://www.researchpublish.com/do wnload.php?

file $=$ An $\% 20$ experimental $\% 20$ study $\% 20$ to $\% 20$ assess5996.pdf\&act=book

[3] Hynniewta. B., Jose, T. T., \& Anjali, K. G. (2017) Knowledge and attitude on child abuse among school teachers in selected urban English medium schools of Udupi District. Manipal Journal of Nursing and Health Sciences, 3(1), 32-36. [cited $2019 \quad$ May 16]URLavailable:http://www.jfmpc.com/article.asp?iss $\mathrm{n}=22494863$; year $=2019$; volume $=8 ;$ issue $=2 ;$ spage $=706 ; \mathrm{e}$ page $=710$; aulast $=$ Alsaleem

[4] "Child abuse and neglect by parents and other caregivers" (PDF). World Health Organization.p.3.[cited 2019Jan19]

URLavailable:https://www.who.int/violenceinjurypreve ntion/violence/globalcampaign/en /chap3.pdf

[5] Ozbey H, Ozcelep GA, Gul U, et al. Knowledge and awareness of nursing students about child abuse and neglect running head: Child abuse and neglect. J Nurs Res Pract. 2018;2(3):21-25. [cited 2019 May 16] URL available: https://www.pulsus.com/scholarlyarticles/knowledge-and-awareness-of-nursing-studentsabout-child-abuse-and-neglect-4658.html

[6] BinshaPappachanC,Knowledge of mothers regarding prevention of child abuse, Innovational Journal of Nursing and Healthcare (IJNH), Vol 3 (1), 7-10, 2017. .[cited 2019 Jan 19] URL available: http://innovationalpublishers.com/Content/uploads /Abstract /405347494_Abstract.pdf

[7] Das D (2018). Assessment of Knowledge Regarding Child Abuse and its Prevention among Mothers of Selected Rural Community, International Journal of Science and Research (IJSR), Vol 7 (4), 1485-88.

[8] Kaur A et.al(2018). An experimental study to assess the effectiveness of structured teaching program on knowledge regarding good touch and bad touch among students .International Journal of Social Science and Humanities Research , 6(2),735-739. [cited 2019 Jan 22]URL available: file:///C: /Users/DELL/Downloads /An\%20experimental\%20stud y\%20to \%20 assess$5996 \% 20(2) . p d f$

[9] Ms. Abujamand Y, Prof A. LillypetS(2017) .Quasi experiment study to determine the effectiveness of structured teaching program on knowledge regarding good touch and bad touch among children. The Nurse; Vol.9,No.4, Jul-Aug: 18-24. [cited 2019 Jan 28] URL available: https://www.researchgate. net/publication/320491117_EFFECTIVENESS_OF_ STRUCTURED_ TEACHING_ PROGRAMME_ON _KNOWLEDGE_REGARDING _GOOD _TOUCH_AND_BAD_TOUCH_ _ _CHILDREN. 